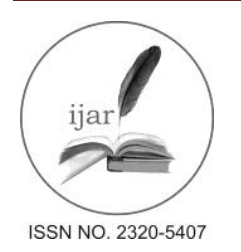

Journal homepage: http://www.journalijar.com
Journal DOI: $10.21474 /$ IAR 01

INTERNATIONAL JOURNAL

Journal DOI: $\underline{10.21474 / \mathrm{JARO1}}$

OF ADVANCED RESEARCH

RESEARCH ARTICLE

\title{
ECOLOGICAL CHARACTERISTICS OF SOIL MICROARTHROPODS OF THE STEPPE ZONE OF MONGOLIA.
}

*Ariunaa Jugder ${ }^{1}$, and Bayartogtokh Badamdorj ${ }^{2}$.

1. Department of Biology and Histology, Mongolian National University of Medical Sciences, Mongolia.

2. Department of Biology, Faculty of Natural Science, MongolianNational University, Mongolia

\section{Manuscript Info}

Manuscript History:

Received: 14 April 2016

Final Accepted: 19 May 2016

Published Online: June 2016

Key words:

Breeding season,

Buffaloe, Post- partum anoestrus.

*Corresponding Author

Ariunaa Jugder.

\begin{abstract}
Territory of Eastern Mongolian steppe characterize by their hilly plane surface that rare with mountains. Total area of the Eastern Mongolia is $300157.0 \mathrm{~km}^{2}$ which is the 19.2 percent of the total territory of Mongolia. Our study area is involves the above mentioned characteristics of the Eastern Mongolian steppe and belong to the Dariganga plane sub region. Samples were collected from different biotopes, such as mountain steppe, meadow, and desert steppe that involve plane area, and hills.However, there are no any specific publications and studies that belong to our study area. Main objective of the study is to determine ecological characteristics of the soil microarthropods in Eastern Mongolian steppe ecosystem. From our investigations we attained the following conclusions: The average density of the Eastern Mongolian steppe soil microarthropods were 6900 and average density of the were Acari: Oribatida $7355 \mathrm{ekz} / \mathrm{m}^{2}$ Biodiversity were poor in the biotopes of birch grove meadow, and in sedge grass meadows, similarly, but the biotopes were high by their species richness. Biotope of steppe with sedge, grass, and forbs were rich by their biodiversity. However, the biotope was poor by its species richness. The poorest biotope by the biodiversity and species richness was mountain steppe with grass and forbs. The differences in the species richness and biodiversity are caused by the differences in soil and vegetation cover and by the differences in sample collection time. Comparison among the biotopes shows that the biotopes were similar by 33$47 \%$ with each other. This indicates that the biotopes are similar by the time of formation and ecological conditions.
\end{abstract}

Copy Right, IJAR, 2016. All rights reserved.

\section{Introduction:-}

The one of the organisms that has important role for the formation of the ecological system in all different zones of the Mongolia are microarthropods. The microarthropods such as Collembola, Thysanura, Diplura, Protura, that are poor developed and preliminary non-wing insect, and Oribatei are the important component of the soil fauna. Average body size of the micro arthropods is 50-900 $\mu \mathrm{m}$ and their density per unit area is relatively high. For example, in soil surface layer or in the moss layer of the forest zone, 200-300 thousand individual / $\mathrm{m}^{2}$ of micro arthropods can be found (Gilyarov, Krivolutskii, 1975).

Diet forms of the soil microarthropods differ greatly among the groups. Some representatives of the microarthropods use excrements or litter for their food and intensity mechanical and chemical decay of the organic matter, which forms suitable condition for the breeding of the microorganisms. By this mean, the microarthropods are the organisms that make the nutrient formation of the soil more rapid. This process have important role to the cycle and change of the natural elements and matter. From the other hand, different groups or representatives of the 
microarthropods distribute in different zones and thus can serve as biological indicators of the soil type and soil formation.

Territory of Eastern Mongolian steppe characterize by their hilly plane surface that rare with mountains. Total area of the Eastern Mongolia is $300157.0 \mathrm{~km}^{2}$ which is the 19.2 percent of the total territory of Mongolia. Our study area is involves the above mentioned characteristics of the Eastern Mongolian steppe and belong to the Dariganga plane sub region. Samples were collected from different biotopes, such as mountain steppe, meadow, and desert steppe that involve plane area, and hills.However, there are no any specific publications and studies that belong to our study area. Main objective of the study is to determine ecological characteristics of the soil microarthropods in Eastern Mongolian steppe ecosystem.

\section{Material and Methods:-}

Study samples were collected in September 2014, from different biotopes such as steppe, mountain steppe, meadow, and grove of birch. Location of this area is Baruun-Urtsoum of the Sukhbaataraimag that belong to the Dariganga, sub region of the Eastern Mongolian steppe. 16 samples were collected from the area and 1105 individuals of the micro arthropods were identified and 126 slides were prepared. In addition, for the comparison purposed we have added another 1387 individuals of 17 samples that were collected from the Erdenetsagaan and Darigangasoums, in July 2014. The territory of the Erdenetsagaan and Darigangasoums belongs to the same sub region as previous samples locations. The Jaknife index, Simpson index, formula of Balogh, similarity coefficient of Sorenson index, Cluster analysiswere used in the ourstudy.

\section{Result and Discussion:-}

Number of the steppe soil microarthropods

There are, in average, 6900 individuals of microarthropods found in $1 \mathrm{~m}^{2}$ of soil surface of the steppe zone. Table 1 shows number of individuals of 90 species per unit area.

Table 1:- Population density of soil microarthropods in the steppe soil

\begin{tabular}{|l|l|c|c|}
\hline \multicolumn{1}{|c|}{ № } & Biotopes & $\begin{array}{c}\text { Number } \\
\text { of species }\end{array}$ & $\begin{array}{c}\text { Individual } \\
\text { number }\left(\mathrm{ekz} / \mathrm{m}^{2}\right)\end{array}$ \\
\hline 1 & Steppe with sedge, grass and forbs & 18 & 4780 \\
\hline 2 & Mountain steppe with grass and forbs & 16 & 1950 \\
\hline 3 & & 31 & 9480 \\
\hline 4 & Birch grove of the river meadow & 20 & 8820 \\
\hline & River meadow with sedges and grasses & 83 & Average: 6900 \\
\hline
\end{tabular}

The table above shows that the density of the microarthropods in the meadow soil is twice higher than the density of steppe with sedges, grass and forbs 4.8 times more than the density of the mountain steppe biotope. The lowest density was observed in the mountain steppe with grass and forbs.

There were eudominants in the eastern steppe soil microarthropods and the dominant species were relatively rare. The table below offers dominant species of the steppe soil microarthropods Table 2 .

Table 2:- Ratio of the dominant microarthropods in the steppe soil.

\begin{tabular}{|l|l|c|c|}
\hline \multicolumn{1}{|c|}{ № } & \multicolumn{1}{|c|}{ Dominant species } & Individual number & $\begin{array}{c}\text { Percentage of } \\
\text { dominance (D) }\end{array}$ \\
\hline 1 & Isotomaviolaceae & 108 & 9.8 \\
\hline 2 & Oppiella nova & 106 & 9.6 \\
\hline 3 & Tectocepheusvelatus & 100 & 9.0 \\
\hline 4 & Protoribatesbayanicus & 96 & 8.7 \\
\hline 5 & Cosmoppiaornata & 73 & 6.6 \\
\hline 6 & Oribatellashaldybinae & 70 & 6.3 \\
\hline 7 & Ceratozetesheteroscuspis & 64 & 5.8 \\
\hline 8 & Pergamasusspinosus & 58 & 5.2 \\
\hline & Total & 675 & 100 \\
\hline
\end{tabular}


The species compose $61 \%$ of the density of Eastern Mongolian microarthropods, in average. In addition, there were recorded 6 eudominants with 506 individuals, 2 sub dominants with 32 individuals found in the Baruun-Urtsoum of the Sukhbaataraimag. These species consists of 80.3 percent of total individuals. In the area of Darigangasoum of Sukhbaatar there were found 2 eudominants with 768 individuals, one dominant with 76 individuals, and 5 subdominants with 242 individuals.

\section{Species richness and biodiversity of the steppe soil microarthropods:-}

We calculated following figures of the species richness and biodiversity of the Eastern Mongolian steppe.

Different biotopes of our study site were relatively poor by their biodiversity and species richness of the microarthropods (Figure 1).
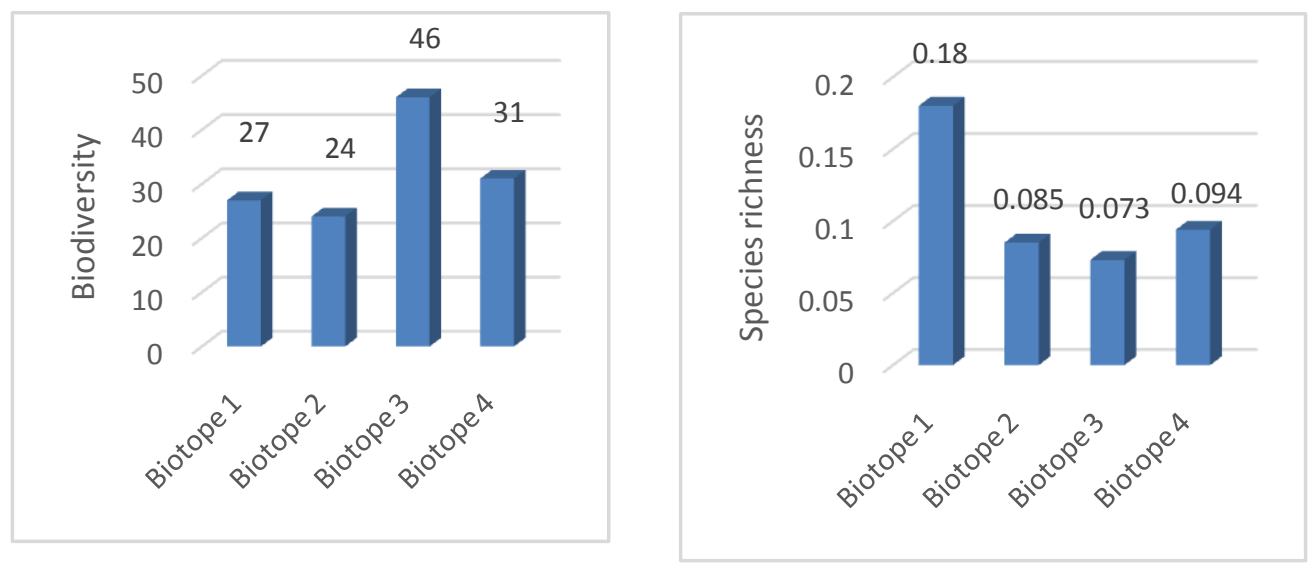

Figure 1:- Species richness and biodiversity of the steppe soil microarthropods

Explanation: Biotope 1 - Steppe with sedge, grass and forbs

Biotope 2 - Mountain steppe with grass and forbs

Biotope 3 - Birch grove of the river meadow

Biotope 4 - River meadow with sedges and grasses

The richest biotope of the eastern steppe by the species richness and biodiversity were steppe with grass but the poorest were steppe with sedge, grass and forbs, mountain steppe with forbs and meadow with sedges. The highest values of the species richness were calculated in the Potentilla and sedge vegetation.

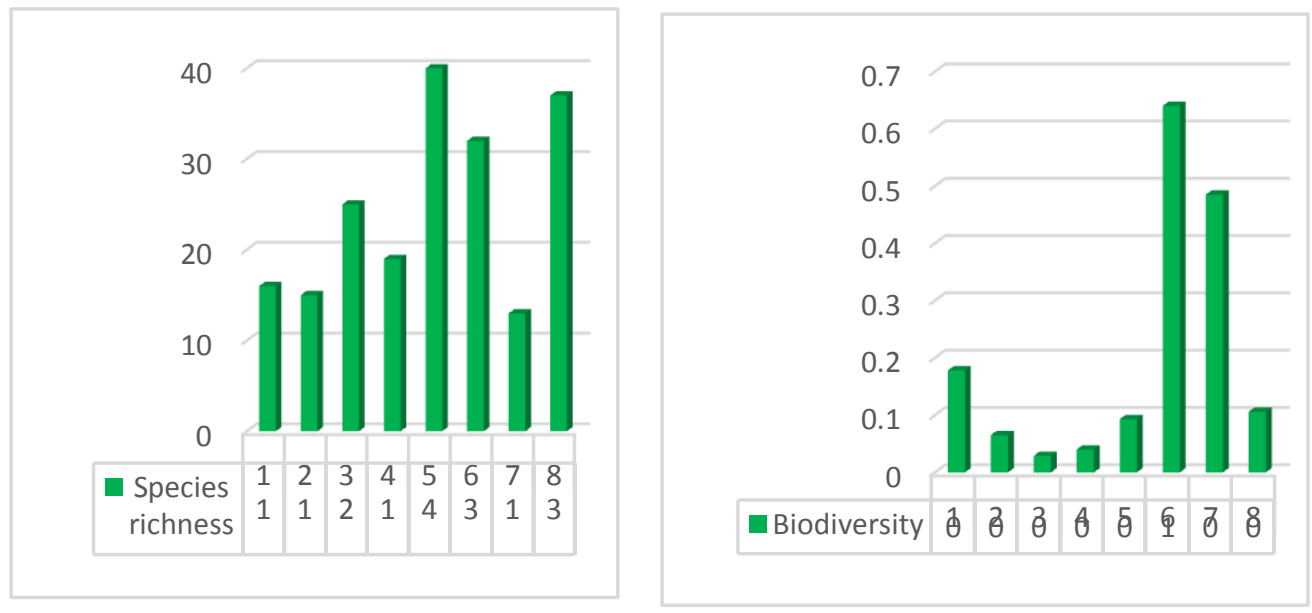

Figure 2:- Biodiversity and species richness of steppe soil Oribatei. 
Explanation: Biotope 1 - Steppe with sedge, grass and forbs

Biotope 2 - Mountain steppe with grass and forbs

Biotope 3 - Birch grove of the river meadow

Biotope 4 - River meadow with sedges and grasses

Biotope 5 - Steppe with Potentilla, Carex

Biotope 6 - Needle grass steppe

Biotope 7 - Sand dunes

Biotope 8 - Mountain steppe with Caragana

Differences in the biodiversity and in the species richness of the soil Oribatei in Eastern steppe soil caused by the difference of vegetation and soil cover. Besides, difference in the sample collection period had some influences (Figure 2).

Similarity in the steppe soil microarthropod communities of steppe biotopes:-

Four biotopes of our study are similar among each other with 33-47\%, wich reveals that is relatively similar by the origin and ecological condition (Table 3 ).

Table 3:- Similarity coefficient of species composition of oribatid in steppe soil.

\begin{tabular}{|c|c|c|c|c|}
\hline Biotopes & 1 & 2 & 3 & 4 \\
\hline 1 & 1 & 0.470 & 0.478 & 0.368 \\
\hline 2 & & 1 & 0.478 & 0.431 \\
\hline 3 & & & 1 & 1 \\
\hline 4
\end{tabular}

Cluster analysis results on soil Oribateishow 2 groupings among the 8 biotopes. 3 of the biotopes formed one cluster and 5 other formed another. The grouping with 3 biotopes included biotopes of the birch grove meadow, grass sedge and forbe steppe and mountain steppe with grass and forbs. Mountain steppe with Caragana and steppe with Potentilla, Carex biotopes were similar in 46-479\% and sand dunes and meadow steppe with sedges and grass were similar in $31 \%$.

Cluster analysis based on the Sorenson index of similarity of the soil microarthropods of eastern Mongolia shows that the microarthropod communities are relatively similar and formed in relatively similar way.

\section{References:-}

1. Bayartogtoch B. (2000). Oribatid Mites of the Genus Scheloribates (Acari: Oribatida: Scheloribatidae) from Mongolia. Edaphologia 65, p 98.

2. Bayartogtoch B.(2001). Oribatid Mites of the Liebstadia (Acari: Oribatida: Scheloribatidae)) from Mongolia with notes on taxanomy of the genus. Journal of natural History. 2001. Vol 35, number Edaphologia 35, number 88 , p 56

3. Bayartogtoch B. (2003). The soil mite family Eremaeidae (Acari: Oribatida) in Mongolia, with remarks on distribution and diversity of known genera. Journal of natural History. 2003. Vol 316 number 8666 p 52.

4. Colloff M, Halliday B. (1998). Oribatid Mites a Catalogue of Australian Genera and species. Monographs on invertebrate taxanomy Vol. 6 p 58

5. Fuiukawa T, Fujita M, Aoki J. (1993). Checklist of Oribatid Mites Of Japan (Acari: Oribatida). Journal of the Acarological society of Japan, Vol. 2 Supplement 1. p 368.

6. Krebs Ch. J. (1989). Ecological Methodology. New York. Harper Collins Publishes, p 150, 295, 312, 329, 336, 357.

7. Krebs Ch. J. (1994). Ecology. New York.. p 114, 138

8. Wallwork A. (1976). The distribution and diversity of soil fauna. New York..p 55-58, 73, 78, 253 - 256, 279

9. Gorny M, Grum L. (1994). Methods in soil zoology. New York. 1993. P 121-129, 140-145 